\title{
Gram-negative bacteria associated with brewery yeasts: reclassification of Obesumbacterium proteus biogroup 2 as Shimwellia pseudoproteus gen. nov., sp. nov., and transfer of Escherichia blattae to Shimwellia blattae comb. nov.
}

Correspondence
Fergus G. Priest
f.g.priest@hw.ac.uk

\author{
Fergus G. Priest and Margaret Barker
}

International Centre for Brewing and Distilling, Heriot Watt University, Edinburgh EH14 4AS, UK
Traditional beer brewing practice involves using a portion of the yeast harvested from a current fermentation as inoculum for the next fermentation. However, this leads to the accumulation of Gram-negative bacteria with the yeast and, after about 10 fermentations, the extent of contamination is such that the yeast is generally discarded in favour of a new, pure-culture inoculum, or it is treated with acid to destroy the contaminating bacteria (Strandskov et al., 1953; Van Vuuren \& Priest, 2003).

Abbreviation: MLST, multilocus sequence typing.

The GenBank/EMBL/DDBJ accession numbers for the $16 \mathrm{~S}$ rRNA gene sequences of Obesumbacterium proteus strains NCIMB $8771^{\top}, 511$ and 540, Shimwellia [Escherichia] blattae DSM 4481' ${ }^{\top}$, and Shimwellia pseudoproteus $521^{\top}$ and Am-4 are FJ267521, FJ492810, FJ267522, FJ267520, FJ267523 and FJ492809, respectively. Accession numbers for protein-coding genes are as follows. S. blattae DSM 4481'ㄹ: fusA, FJ267524; leuS, FJ267525; pyrG, FJ267526; and rpoB, FJ267527. O. proteus NCIMB 8771': fusA, FJ267528; leuS, FJ267529; pyrG, FJ267530; and rpoB, FJ267531. O. proteus 511: fusA, FJ492813; leuS, FJ492816; pyrG, FJ492819; and rpoB, FJ492822. O. proteus 540: fusA, FJ492811; leuS, FJ492814; pyrG, FJ492817; and rpoB, FJ492820. S. pseudoproteus 521': fusA, FJ267532; leuS, FJ267533; pyrG, FJ267534; and rpoB, FJ267535. S. pseudoproteus Am-4: fusA, FJ492812; leuS, FJ492815; pyrG, FJ492818; and rpoB, FJ492821.

Details of strains used in the construction of MLST and 16S rRNA gene trees are available as supplementary material with the online version of this paper.
These bacteria were first isolated in pure culture in 1936 and classified as Flavobacterium proteus (Shimwell, 1936; Shimwell \& Grimes, 1936). Later, the genus Obesumbacterium was created for these bacteria, with Obesumbacterium proteus as the sole species (Shimwell, 1963, 1964). More detailed taxonomic investigation assigned Obesumbacterium to the Enterobacteriaceae and revealed two distinct taxa within $O$. proteus, referred to as biogroups 1 and 2 (Priest et al., 1973). These two biogroups have been substantiated by various phenotypic (Prest et al., 1994; van Vuuren et al., 1981) and molecular methods such as ribotyping (Koivula et al., 2006; Prest et al., 1994) and PCR procedures (Maugueret \& Walker, 2002). DNA-DNA hybridization studies indicated that biogroup 1 strains share $75-78 \%$ renaturation with Hafnia alvei and that biogroup 2 strains have an affinity with Escherichia blattae, a bacterium isolated from the hindgut of cockroaches (Burgess et al., 1973; Brenner, 1981). In this study, the almost complete sequences of the 16S rRNA genes and partial sequences of four protein-coding genes (fusA, leuS, pyrG and rpoB) of reference strains of $O$. proteus, a novel isolate of biogroup 2 from brewery yeast, and the type strain of Escherichia blattae have been determined. Phylogenetic analyses using these and reference sequences confirmed that $O$. proteus biogroup 1 is closely related to Hafnia alvei, but revealed that O. proteus biogroup 2 strains and Escherichia blattae are phylogeneti- 
cally distinct and together merit separate generic status within the family Enterobacteriaceae as two species.

Bacteria were grown routinely on nutrient agar at $30{ }^{\circ} \mathrm{C}$. They included O. proteus biotype 1 strain NCIMB $8771^{\mathrm{T}}$ and two biotype 1 isolates from ale brewery yeasts from the UK, strains 511 and 540 (=LMG 3048) (Priest et al., 1973). O. proteus biotype 2 strain 521 (=DSM $3038=$ LMG 24835) has been described previously (Priest et al., 1973). Escherichia blattae DSM $4481^{\mathrm{T}}$ was obtained from the DSMZ, Braunschweig, Germany. O. proteus Am-4 (available as LMG 24836) was isolated from ale brewery yeast from Edinburgh; the yeast sample was plated directly on MacConkey agar supplemented with $25 \mu \mathrm{g}$ cycloheximide $\mathrm{ml}^{-1}$ and incubated at $30{ }^{\circ} \mathrm{C}$ for 2 days. Small, lactosenegative colonies were purified by plating on the same medium. DNA was prepared from strains grown in nutrient broth for $18 \mathrm{~h}$ at $30{ }^{\circ} \mathrm{C}$. The culture $(2 \mathrm{ml})$ was centrifuged and DNA was isolated using a PureGene isolation kit as described by the manufacturer. 16S rRNA genes were amplified and sequenced using standard primers at an annealing temperature of $56{ }^{\circ} \mathrm{C}: 27 \mathrm{~F}, 5^{\prime}-$ AGAGTTTGATCMTGGCTCAG-3'; 926F，5'-AAACTCAAAGGAATTGACGG-3'; 685R3， 5'-TCTACGCATTTCACCGCTAC-3'; 1100R, 5'-GGGTTGCGCTCGTTG-3'; and 1492R, 5'-TACGGYTACCTTGTTACGACTT-3'. Genes for fusA, leuS, pyrG and rpoB were amplified and sequenced using the primers described by Salerno et al. (2007) (annealing temperatures in parentheses): fusA3-fusA4 $\left(58{ }^{\circ} \mathrm{C}\right)$, leuS3-leuS4 $\left(58{ }^{\circ} \mathrm{C}\right)$, pyrG3-pyrG4 $\left(55^{\circ} \mathrm{C}\right)$ and VIC4-VIC6 $\left(55^{\circ} \mathrm{C}\right)$. PCR mixtures $(50 \mu \mathrm{l})$ contained $0.2 \mathrm{mM}$ of each nucleotide in $10 \times \mathrm{NH}_{4}$ buffer (Bioline), $0.25 \mu \mathrm{M}$ primers, $2.5 \mathrm{mM} \mathrm{MgCl}_{2}$ for protein-coding genes (2.0 $\mathrm{mM} \mathrm{MgCl} 2$ for $16 \mathrm{~S}$ rRNA genes), and $100 \mathrm{ng}$ DNA template, made up to $49.7 \mu \mathrm{l}$ with sterile deionized water. The PCR comprised denaturation at $95{ }^{\circ} \mathrm{C}$ for $5 \mathrm{~min}$, followed by the addition of $0.3 \mu \mathrm{l}$ Biotaq enzyme ( $5 \mathrm{U} \mathrm{\mu l}^{-1}$; Bioline). There were 30 cycles of denaturation at $95{ }^{\circ} \mathrm{C}$ for $1 \mathrm{~min}$, annealing for $2 \mathrm{~min}$ and elongation at $72{ }^{\circ} \mathrm{C}$ for $2 \mathrm{~min}$. Final elongation was at $72{ }^{\circ} \mathrm{C}$ for $10 \mathrm{~min}$ and samples were stored at $4{ }^{\circ} \mathrm{C}$. Amplification products were checked using agarose gel electrophoresis, purified by polyethylene glycol precipitation (Embley, 1991) and sequenced by MWG Biotech. Forward and reverse sequences were assembled using STADEN software.

16S rRNA gene sequences (1349-1352 bases) for representative Enterobacteriaceae species were obtained from GenBank. Wherever possible, sequence data from the type strains were chosen and strains were selected to match the multilocus sequence typing (MLST) data of Salerno et al. (2007). Details of the strains used and accession numbers of the gene sequences are given in Supplementary Table S1 (available in IJSEM Online). Sequences were aligned using CLUSTAL_X and neighbour-joining trees were constructed. The trees were visualized using TREEVIEW 1.6.6 (Page, 1996). Bootstrap values (\%) were determined for 1000 replications using CLUSTAL_X. Maximum-parsimony trees were constructed using MEGA version 4 (Tamura et al., 2007).
The four protein-coding alleles were concatenated to provide sequences of 2082 bases (fusA, 633; leuS, 642; pyrG, 306; and $r p o B, 501)$, with the exception of Haemophilus influenzae Rd KW20, which was 2085 bases due to a $3 \mathrm{bp}$ insertion in rpoB. Nucleotide sequences for MLST were obtained from GenBank (EU010012EU010119). Sequences were aligned and neighbour-joining trees were constructed as described above.

Yeast from three breweries in the south of Scotland was examined for the presence of Gram-negative bacteria by culturing on MacConkey agar containing cycloheximide to inhibit yeast growth. Only one sample contained lactosenegative bacteria typical of $O$. proteus, which were recovered in pure culture as strain Am-4. The bacterium was isolated from the only brewery that did not practice acid-washing of its yeast to remove contaminating organisms. Almost complete 16S rRNA gene sequences (1412-1496 bases) were prepared from: O. proteus biogroup 1 strains NCIMB $8771^{\mathrm{T}}, 511$ and 540; O. proteus biogroup 2 strains 521 and Am-4; and Escherichia blattae DSM $4481^{\mathrm{T}}$. The sequences were aligned with $16 \mathrm{~S}$ rRNA gene sequences of representatives of the Enterobacteriaceae and a phylogenetic tree was constructed (Fig. 1). This revealed that the two biogroups of $O$. proteus were distantly related. The three biogroup 1 strains had identical $16 \mathrm{~S}$ rRNA genes that showed $99 \%$ similarity with that of Hafnia alvei ATCC $13337^{\mathrm{T}}$. In the O. proteus NCIMB $8771^{\mathrm{T}}$ sequence of 1436 bases, there were seven ambiguous bases at positions 434 (A or $\mathrm{G}), 971$ (A or $\mathrm{G}), 972$ ( $\mathrm{G}$ or C), 973 (C or T), 980 (A or $\mathrm{G}), 981$ ( $\mathrm{G}$ or $\mathrm{C}$ ) and $982(\mathrm{C}$ or $\mathrm{T})$. These probably represent intragenomic variation in the rRNA genes since they lie in regions ( $\mathrm{H} 17$ and $\mathrm{H} 33$ ) noted for such heterogeneity (Case et al., 2007). The two $16 \mathrm{~S}$ rRNA gene sequences from $O$. proteus biogroup 2 strains 521 and Am-4 were identical and shared $99 \%$ similarity with that of Escherichia blattae DSM $4481^{\mathrm{T}}$. Moreover, the Escherichia blattae 16S rRNA gene sequence shared little similarity with those of the type strains of Escherichia coli and Escherichia fergusonii (95 and $96 \%$, respectively) showing that the bacterium is incorrectly placed in the genus Escherichia. Trees constructed using maximumparsimony were similar topologically to the neighbourjoining tree and, in particular, confirmed that $O$. proteus biogroup 1 strains were closely related to Hafnia alvei with Serratia liquefaciens as a close relative, whereas the biogroup 2 strains included Escherichia blattae and formed a cluster with Erwinia amylovora and representatives of the genus Pantoea (data not shown).

To understand the phylogenetic positions of the O. proteus biogroups in more detail, the four protein-coding genes as used for the MLST of Plesiomonas shigelloides (Salerno et al., 2007) were analysed. The fifth gene from the MLST study, $r e c G$, was not amplified in our strains using the recommended primers. Trees derived from the individual gene sequences, together with reference sequences from GenBank, showed limited topological variation suggesting limited horizontal gene transfer (data not shown). A 


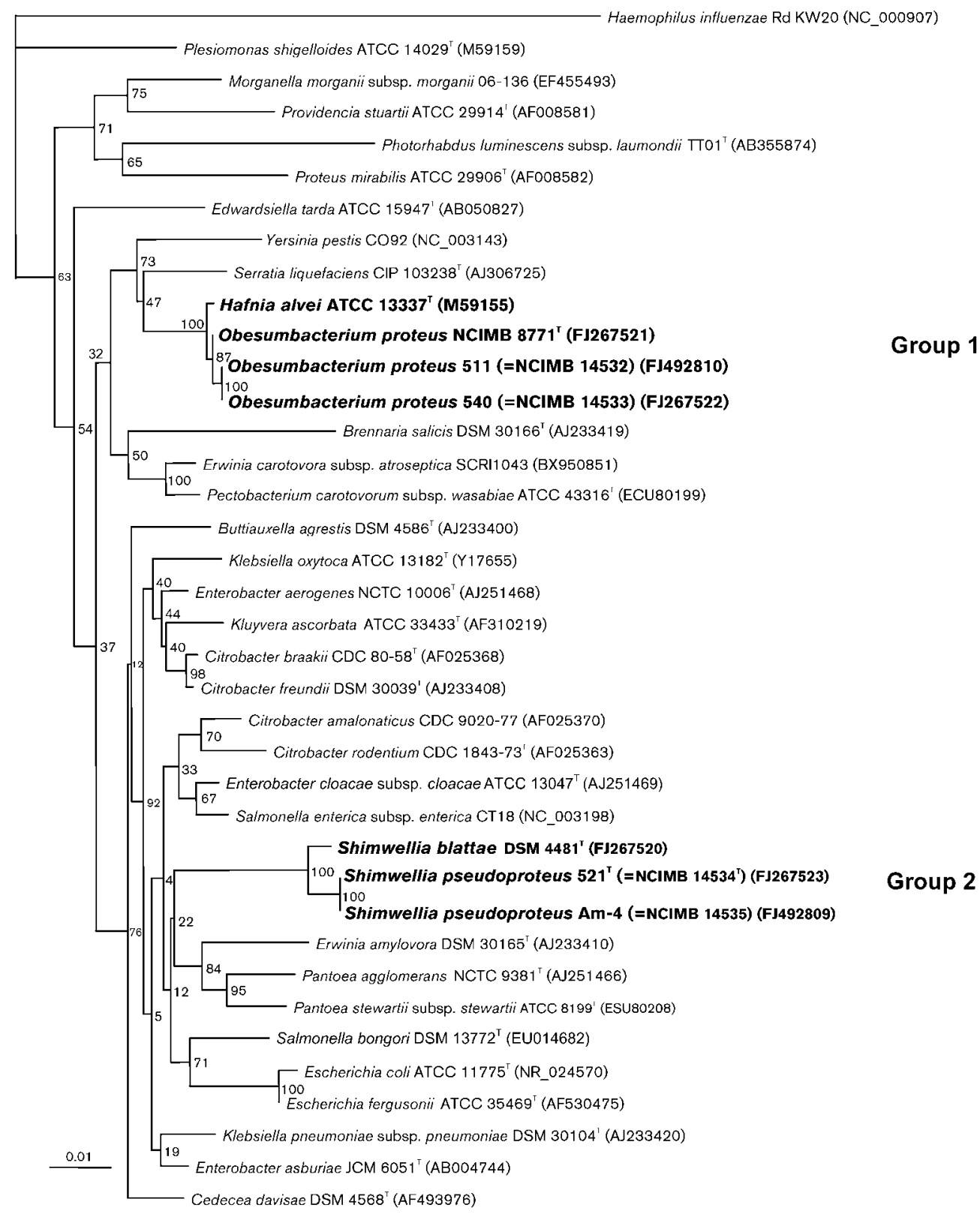

Fig. 1. Neighbour-joining tree of representative strains from the Enterobacteriaceae using almost complete 16S rRNA gene sequences. Numbers at nodes are bootstrap values (\%; 1000 replicates). Bar, 0.01 nt substitutions per site.

consensus tree derived from the concatenated gene sequences is shown in Fig. 2. The three O. proteus biogroup 1 strains had identical sequences for all alleles, as did the two biogroup 2 strains. The MLST tree supported the $16 \mathrm{~S}$ rRNA gene tree and again showed that the two biogroups of $O$. proteus are phylogenetically distinct: biogroup 1 strains were closely related to Hafnia alvei, whereas the biogroup 2 strains formed a monophyletic group with Escherichia blattae. As with the rRNA tree, Escherichia blattae was distinct phylogenetically from other species of the genus Escherichia.
Protein-coding genes tend to accumulate more mutations than rRNA genes and can provide insight into species relationships at a higher resolution than rRNA genes. Alignments of the MLST fragments (2082 bases) were compared for all cases in which there was more than one species representing a genus. The two most closely related species within a genus were Escherichia coli and Escherichia fergusonii (98\%) and the two most distant species within a genus were Pantoea agglomerans and Pantoea stewartii subsp. stewartii ( $86 \%)$. For the 12 comparisons covering Citrobacter, Escherichia, Enterobacter, Pantoea and 


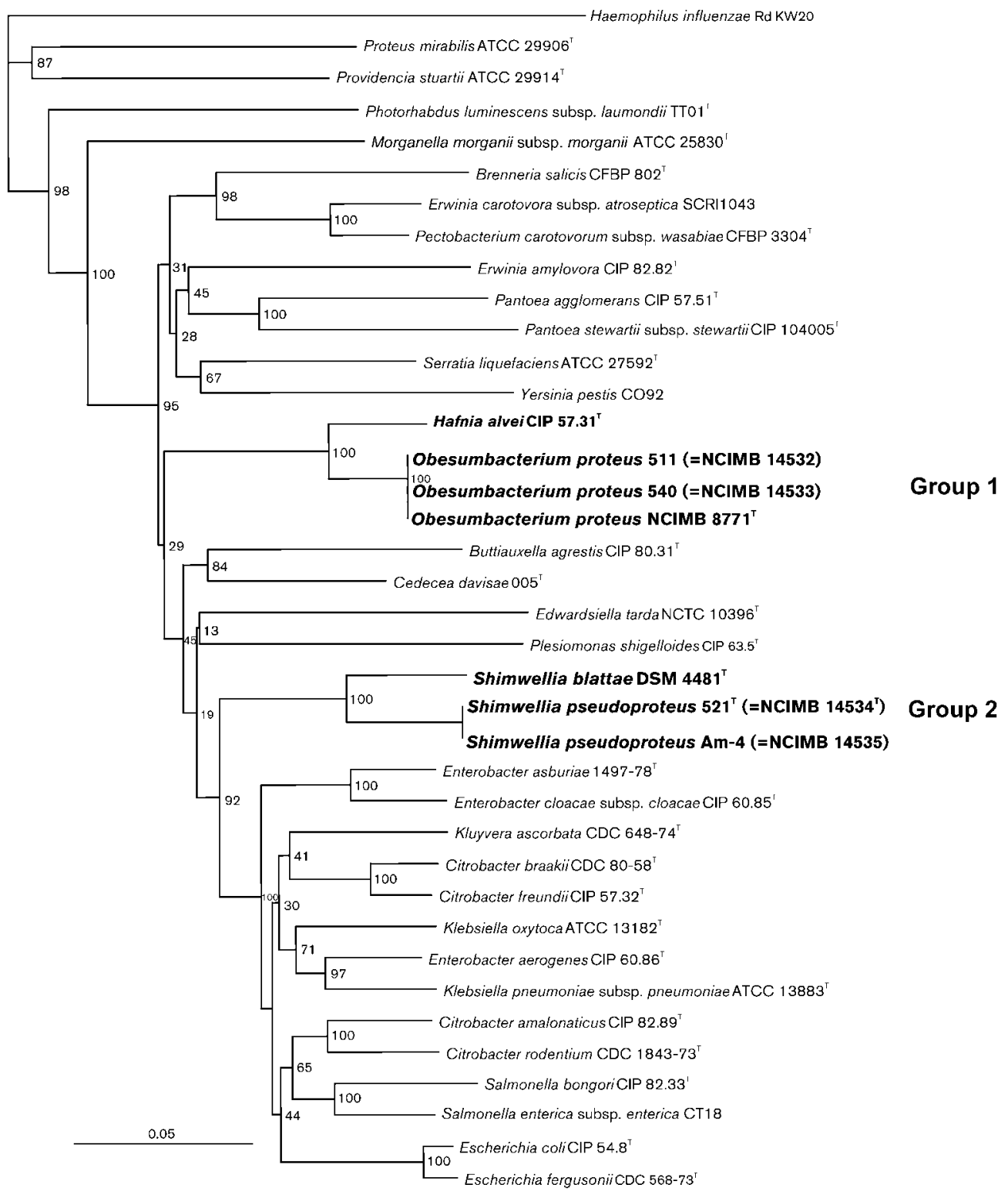

Fig. 2. Neighbour-joining tree of representative strains from the Enterobacteriaceae using the concatenated sequences of four loci (fusA, leuS, pyrG and rpoB). With the exception of Morganella morganii subsp. morganii, strains used are the same as those for Fig. 1, but in some cases type strains were from different culture collections (see Supplementary Table $\mathrm{S} 1$ available in IJSEM Online). Numbers at nodes are bootstrap values (\%; 1000 replicates). Bar, 0.05 nt substitutions per site.

Salmonella species, the mean similarity over the 2082 bases was $92.2 \%$ (3.25 standard deviation). In this context, $O$. proteus biogroup 2 strains and Escherichia blattae shared $93 \%$ similarity, providing convincing evidence that they represent distinct species.

The molecular classification of these bacteria is generally supported by phenotype. The original numerical classification adequately separated $O$. proteus biotypes 1 and 2 and key diagnostic tests are shown in Table 1. Phenotypic descriptions of these bacteria based on larger numbers of strains have been published by Priest et al. (1973), van Vuuren et al. (1981) and Farmer \& Brenner (2005).

The genus Obesumbacterium has been associated with brewery yeasts for more than 40 years and we have shown that biogroup 2 strains, at least, still occupy this environmental niche. Biogroup 1 strains are less common in breweries than those of biogroup 2 (Priest et al., 1973) and have also been associated with the intestines of fish (Skrodenyte-Arbaciauskiene et al., 2006) and edible snails (Charrier et al., 2006), whereas biogroup 2 strains have not 
Table 1. Differential phenotypic characteristics of Obesumbacterium proteus biogroup 1, Shimwellia pseudoproteus sp. nov., Shimwellia blattae comb. nov. and Hafnia alvei

Taxa: 1, O. proteus biogroup 1; 2, Shimwellia pseudoproteus sp. nov. (previously O. proteus biogroup 2); 3, Shimwellia blattae comb. nov. (previously Escherichia blattae); 4, Hafnia alvei. +, $90 \%$ or more positive; -, 0-9.9\% positive; v, 10.0-89.9\% positive. Data from Brenner (1981) and Farmer \& Brenner (2005).

\begin{tabular}{|lcccc|}
\hline Characteristic & $\mathbf{1}$ & $\mathbf{2}$ & $\mathbf{3}$ & $\mathbf{4}$ \\
\hline Catalase & + & Delayed $^{*}$ & + & + \\
Aesculin hydrolysis & + & - & - & $\mathrm{V}$ \\
Malonate utilization & $\mathrm{V}$ & - & + & $\mathrm{V}$ \\
Motility (24 h) & - & - & - & + \\
Acid production from: & & & & \\
$\quad$ L-Arabinose & $\mathrm{V}$ & - & + & + \\
$\quad$ Mannitol & + & - & - & + \\
$\quad$ Salicin & + & - & - & $\mathrm{V}$ \\
$\quad$ D-Xylose & - & $\mathrm{V}$ & + & + \\
Gas from glucose & - & - & + & + \\
Voges-Proskauer test & + & - & - & + \\
\end{tabular}

${ }^{\star}$ The catalase reaction is weak and delayed by about $30 \mathrm{~s}$.

been isolated outside the brewery. The original O. proteus isolate of Shimwell has been lost (Farmer \& Brenner, 2005) and the current type strain was provided by F. B. Strandskov and J. B. Bockelmann, who isolated the bacterium from yeast in their North American brewery, although its similarity to the original isolate was substantiated by J. L. Shimwell. However, the descriptions at that time were limited and, as discussed by Farmer and Brenner, were not definitive (Farmer \& Brenner, 2005). So we do not know whether Shimwell's original isolates were of biogroup 1 or 2 . Farmer \& Brenner (2005) refer to $O$. proteus biogroup 1 strains as Hafnia alvei biogroup 1 because of their close relationship with Hafnia alvei on the basis of DNA-DNA reassociation (75\% renaturation). However, our comparison of the MLST sequences showed only $95 \%$ similarity between these taxa which, while greater than the mean similarity of $92 \%$ between species, is less than that which separates the two Escherichia species included in this study ( $98 \%$ ) or Citrobacter freundii from Citrobacter braakii $(96 \%)$. It is therefore recommended that $O$. proteus biogroup 1 strains retain the name $O$. proteus until the systematics of the genus Hafnia have been clarified (Janda \& Abbott, 2006) and the relationships between these bacteria and Hafnia alvei are understood more clearly. This leaves the O. proteus biogroup 2 strains, which represent a distinct taxonomic entity within the Enterobacteriaceae and for which the name Shimwellia pseudoproteus gen. nov., sp. nov. is proposed. Strain 521, isolated from yeast from Davenports Brewery, Birmingham, UK, in 1972 is the earliest extant strain and, as such, it is proposed that this strain be designated the type strain of the novel species. It is also recommended that
Escherichia blattae is transferred to the genus Shimwellia as Shimwellia blattae comb. nov. Phenotypic features that distinguish these taxa are shown in Table 1.

\section{Description of Shimwellia gen. nov.}

Shimwellia (Shim.wel'li.a. N.L. fem. n. Shimwellia named after J. L. Shimwell who first isolated the bacterium).

Cells are non-motile, straight Gram-stain-negative rods that occur singly. Members conform to the general description of the family Enterobacteriaceae. Aerobic and facultatively anaerobic. Oxidase-negative and catalase-positive, although this reaction is delayed and weak in the type species. Cells reduce nitrate to nitrite, do not grow in $\mathrm{KCN}$ and do not produce $\mathrm{H}_{2} \mathrm{~S}$. The type species is Shimwellia pseudoproteus.

\section{Description of Shimwellia pseudoproteus sp. nov.}

Shimwellia pseudoproteus (pseu.do.pro'te.us. Gr. adj. pseudes false; L. n. proteus the ancient sea-god, noted for being able to change his form at will, and also a bacterial epithet; N.L. masc. n. pseudoproteus, the false [Obesumbacterium] proteus).

This description is taken from Priest et al. (1973), Brenner (1981) and Farmer \& Brenner (2005). Displays the following properties in addition to those given in the genus description. There is a tendency for shapes to be pleomorphic on initial isolation. Mesophilic with optimum growth near $30{ }^{\circ} \mathrm{C}$ and between $\mathrm{pH} 4.5$ and 8.0. After growth on nutrient agar for $48 \mathrm{~h}$, cells form small, circular, entire colonies, $1.0-1.5 \mathrm{~mm}$ in diameter with a convex elevation and smooth glassy surface. Acid, but no gas, is produced from glucose, rhamnose and trehalose. No acid is produced from lactose, mannitol, salicin or numerous other sugars. Does not utilize malonate. Arginine dihydrolase-negative, lysine decarboxylase-positive. VogesProskauer-negative. The DNA G+C content is $48 \pm$ $1 \mathrm{~mol} \%$.

The type strain is $521^{\mathrm{T}}\left(=\mathrm{DSM} 3038^{\mathrm{T}}=\mathrm{LMG} 24835^{\mathrm{T}}\right.$ $=$ NCIMB $14534^{\mathrm{T}}$ ), isolated from ale brewery yeast in Birmingham, UK. Strain Am-4 is an additional strain of the species.

\section{Emended description of Shimwellia blattae comb. nov.}

Shimwellia blattae (blat'tae. L. fem. n. blatta cockroach; L. gen. n. blattae of the cockroach).

Basonym: Escherichia blattae Burgess et al. 1973.

The description is the same as that given by Burgess et al. (1973) and Scheutz \& Strockbine (2005) with the following additional properties, including those given in the genus description. After growth on nutrient agar for $48 \mathrm{~h}$, colonies are 1-5 mm diameter, circular, smooth, glossy, creamy in colour with a convex elevation and an entire margin. Acid and gas are produced from glucose; acid is 
produced from L-arabinose, glycerol, D-mannose, L-rhamnose and D-xylose. Methyl-red-positive, indole-negative. Arginine dihydrolase-negative; positive for lysine and ornithine decarboxylases. Voges-Proskauer-negative. The DNA $\mathrm{G}+\mathrm{C}$ content has not been determined.

The type strain is ATCC $29907^{\mathrm{T}}\left(=\mathrm{CDC} 9005-74^{\mathrm{T}}=\mathrm{CIP}\right.$ $103175^{\mathrm{T}}=$ CIP $104942^{\mathrm{T}}=$ DSM $\quad 4481^{\mathrm{T}}=$ HAMBI $1692^{\mathrm{T}}=$ JCM $1650^{\mathrm{T}}=$ LMG $3030^{\mathrm{T}}=$ NCTC $12127^{\mathrm{T}}$ ).

\section{Acknowledgements}

We are grateful to Dr J. J. Farmer III for helpful discussions and to Dr J. P. Euzéby for advice on nomenclature.

\section{References}

Brenner, D. J. (1981). Introduction to the family Enterobacteriaceae. In The Prokaryotes, pp. 1105-1127. Edited by M. P. Starr, H. Stolp, H. Trüper \& H. G. Schlegel. Berlin: Springer-Verlag.

Burgess, N. R. H., McDermott, S. N. \& Whiting, J. (1973). Anaerobic bacteria occurring in the hind-gut of the cockroach, Blatta orientalis. J Hyg Camb 71, 1-6.

Case, R. J., Boucher, Y., Dahllöf, l., Holmström, C., Doolittle, W. F. \& Kjelleberg, S. (2007). Use of $16 \mathrm{~S}$ rRNA and $r p o B$ genes as molecular markers for microbial ecology studies. Appl Environ Microbiol 73, 278-288.

Charrier, M., Fonty, G., Gaillard-Martinie, B., Ainouche, K. \& Andant, G. (2006). Isolation and characterization of cultivable fermentative bacteria from the intestine of two edible snails, Helix pomatia and Cornu aspersum (Gastropoda: Pulmonata). Biol Res 39, 669-681.

Embley, T. M. (1991). The linear PCR reaction: a simple and robust method for sequencing amplified rRNA genes. Lett Appl Microbiol 13, 171-174.

Farmer, J. J. \& Brenner, D. J. (2005). Genus XXII. Obesumbacterium Shimwell 1963, 759 ${ }^{\mathrm{AL}}$. In Bergey's Manual of Systematic Bacteriology, The Proteobacteria, Part B: The Gammaproteobacteria, 2nd edn, vol. 2, pp. 710-713. Edited by G. Garrity, D. J. Brenner, N. R. Krieg \& J. R. Staley. New York: Springer.

Janda, J. M. \& Abbott, S. L. (2006). The genus Hafnia: from soup to nuts. Clin Microbiol Rev 19, 12-18.

Koivula, T. T., Juvonen, R., Haikara, A. \& Suihko, M. L. (2006). Characterization of the brewery spoilage bacterium Obesumbacterium proteus by automated ribotyping and development of PCR methods for its biotype 1. J Appl Microbiol 100, 398-406.
Maugueret, T. M. \& Walker, S. L. (2002). Rapid detection of Obesumbacterium proteus from yeast and wort using polymerase chain reaction. Lett Appl Microbiol 35, 281-284.

Page, R. D. M. (1996). TreeView: An application to display phylogenetic trees on personal computers. Comput Appl Biosci 12, 357-358.

Prest, A. G., Hammond, J. R. \& Stewart, G. S. (1994). Biochemical and molecular characterization of Obesumbacterium proteus, a common contaminant of brewing yeasts. Appl Environ Microbiol 60, 1635-1640.

Priest, F. G., Somerville, H. J., Cole, J. A. \& Hough, J. S. (1973). The taxonomic position of Obesumbacterium proteus, a common brewery contaminant. J Gen Microbiol 75, 295-307.

Salerno, A., Delétoile, A., Lefevre, M., Ciznar, I., Krovacek, K., Grimont, P. \& Brisse, S. (2007). Recombining population structure of Plesiomonas shigelloides (Enterobacteriaceae) revealed by multilocus sequence typing. J Bacteriol 189, 7808-7818.

Scheutz, F. \& Strockbine, N. A. (2005). Genus I. Escherichia Castellani and Chalmers 1919, 941 ${ }^{\mathrm{AL}}$. In Bergey's Manual of Systematic Bacteriology, The Proteobacteria, Part B: The Gammaproteobacteria, 2nd edn, vol. 2, pp. 607-625. Edited by G. Garrity, D. J. Brenner, N. R. Krieg \& J. R. Staley. New York: Springer.

Shimwell, J. L. (1936). A study of the common rod bacteria of brewers' yeast. J Inst Brew 42, 119-127.

Shimwell, J. L. (1963). Obesumbacterium gen. nov. Brew J 49, 759-760.

Shimwell, J. L. (1964). Obesumbacterium, a new genus for the inclusion of "Flavobacterium proteus". J Inst Brew 70, 247-248.

Shimwell, J. L. \& Grimes, M. (1936). The distinguishing characters of Flavobacterium proteus (sp. nov.), the common rod bacterium of brewers' yeast. J Inst Brew 42, 348-350.

Skrodenyte-Arbaciauskiene, V., Sruoga, A. \& Butkauskas, D. (2006). Assessment of microbial diversity in the river trout Salmo trutta fario L. intestinal tract identified by partial $16 \mathrm{~S}$ rRNA gene sequence analysis. Fish Sci 72, 597-602.

Strandskov, F. B., Baker, H. W. \& Bockelmann, J. B. (1953). A study of the gram-negative bacterial rod infection of brewery yeast and brewery fermentations. Wallerstein Lab Commun 16, 261-270.

Tamura, K., Dudley, J., Nei, M. \& Kumar, S. (2007). MEGA4: Molecular Evolutionary Genetics Analysis (MEGA) software version 4.0. Mol Biol Evol 24, 1596-1599.

Van Vuuren, H. J. J. \& Priest, F. G. (2003). Gram-negative brewery bacteria. In Brewing Microbiology, pp. 219-245. Edited by F. G. Priest \& I. Campbell. New York: Kluwer Academic/Plenum Publishers.

van Vuuren, H. J., Kersters, K., De Ley, J. \& Toerien, D. F. (1981). The identification of Enterobacteriaceae from breweries: combined use and comparison of API 20E system, gel electrophoresis of proteins and gas chromatography of volatile metabolites. J Appl Bacteriol 51, 51-65. 